\title{
DETERMINANT OF ISLAMIC SOCIAL REPORTING ON COMPANY REGISTERED AS INDONESIA SYARIA STOCK INDEX
}

Faculty of Economics and Business

Universitas Muhammadiyah Jakarta

zulfikar.ramadhan@umj.ac.id

\begin{abstract}
The purpose of this study is to study several factors that influence the Islamic Social Reporting Company. These factors are company size and profitability. The variables in this study are company size and profitability, while the dependent variable is Islamic Social Reporting. The research method uses explanation research with a quantitative approach. The sample of this study is a company registered as the Indonesian Syariah Stock Index in 2016. The sample was selected by purposive sampling method which obtained 179 samples. Data Assumption Test for bias data bias bias. Test of Multiple Linear Regression Analysis, Determination Coefficient Test, Statistical Test and Statistical Test to test the hypothesis. Based on this research, it can be proven that leverage has a positive and insignificant effect on the Islamic Social Reporting Company in the form of the Indonesian Islamic Stock Index, while the positive and significant profitability of the Islamic Social Reporting Company in the form of the Indonesian Islamic Stock Index. In addition, leverage and profitability together have a positive and significant effect on the Islamic Social Reporting Company in the form of the Indonesian Islamic Stock Index.
\end{abstract}

Keywords: leverage, profitability, Islamic Social Reporting.

\section{INTRODUCTION}

This is a fact that a company which is present in one environment will bring both positive and negative impact for that environment. There are somepositive impacts such as it gives the availability of job opportunity, provides the things needed by society to be consumed, pays the tax gives donation, etc. However, there are some excessive negative externalities of industrialization such as some national-scale and international-scale cases of global warming,air pollution, poisoning, noise, discrimination, coercion, 'haram' (forbidden) food production, radiation as well as the present of deadly sickness because of the infection of chemistry from industrialization.

Corporate Social Responsibilityis a general discourse in business in Indonesia,this phenomenon is because of the increasing trends of CSR on business. The practice and the disclosure of CSR in Indonesia has grown up with the raising attention of global society concern toward the development of transnational or multinational company which operate in Indonesia. Besides, the disclosure of CSR is also related to the damage of environment in Indonesia such as deforestation, air pollution, water pollutin, climate change, etc. In the share market, that condition is seen from the implementation of index 
which includes stocks of companies with CSR practice.

The company which can implement a good CSR, it will give a feedback for that company in the form of public support and social strengthening factor and sustainable development. Furthermore, the success of company commercial will be determined by how the company can manage its social responsibility towards its operational surrounding community.

The development of CSR in Islamic economic also impacted on the increase of community attention towards syaria institutions or syaria institution. This increasing attention indicated that the needs of society towards syaria institution have grown up from time to time. The syaria stock market as an institution and profession whih had important rules in increasing the syaria share market companies which wanted to participate in syaria stock market in Indonesia. In Indonesia, the development of syaria stock market was started by the establishment of Jakarta Islamic Index (JII).

Othman and Thani (2010) explained that the fast development of syaria stock market made companies included in the list of syaria stockwhich is epected to preview a religious dimension on the disclosure of annual report aiming at giving benefits for the muslim stakeholders. Thus, a guideline was needed to determine howfar these companies which were listed in the syaria stock could make social reporting which included the religious aspects in annual report. Othman et al. (2009) developed the relevant disclosure index which has been mentioned before in the Islamic Social Reporting (ISR) Index. ISR was firstly stated by Haniffa (2002), then it was extensively developed by Othman et al. (2009) in Malaysia. Haniffa (2002) stated that there was limits on the social conventional reporting ; therefore, she stated the frame concept of Islamic Social Reporting based on the syaria provision which not only helped the company to fulfill its responsibility toward Allah SubhanaahuwaTa'alaand community.

Some researchers who have conducted research on ISR wereHaniffa (2002), Haniffaand Hudaib (2007), Othman et al (2009), Othman and Thani (2010), Lestari (2013), Putri (2014), and some researchs have been done in some universities in Indonesia.

Islamic Social Reporting is the benchmark of the implementation of the social performance in syaria banking and other syaria business included the compilation of CSR standard set by AAOIFI which later was developed by the researchers about the items of CSRwith Islamic entity. Items of Islamic Social Reportingwhich were developed were called Index ISR. Specifically, this index is the extension of social reportingincluded the community expectation about the company's role in economy and company's role in the spiritual perspective. ISR index was trusted to be the first step on CSR disclosure based on Islamic perspetive (Fitriaand Hartati, 2010).

In a view of that, Othman et al. (2009) developed relevant disclosure with items mentioned before on the Islamic Social Reporting (ISR) Index. Islamic Social Reportingwas firstly 
found by Haniffa (2002) and it was developed extensively by Othman et al. (2009) in Malaysia. Haniffa (2002) stated there was limitation on Conventional Reporting therefore, by the concept of Islamic Social Reportingwith syaria based would not only help the decision making for muslimbut also to help the company to fulfill its responsibility to Allah SubhanaahuwaTa'alaand community.

After that, in line with the development of syaria economy, stock market in Indonesia followed to develop by presenting the latest syaria index which was Syaria Indonesia Stock Index. Indonesia Syaria Stock Index (ISSI) noted there was a growth for about $20 \%$ year to year per 20 September 2016. This made ISSI as the highest stock index growth of all global syaria stocks. Furthermore, according to Head of Islamic Capital Market Development of Indonesia Stock Exchange IrwanAbdalloh, in the past five years, Indonesia Syaria Stock Index (ISSI) grew for about $43 \%$ higher than that of Composite Stock Price Index (IHSG) which grew for about $41 \%$. (http://finansial.bisnis.com)

The capitalization of Indonesia syariastock index noted the increase growth despite the fluctuative stock value listed in syaria stock. Until Wednesday (19/7/2017), the capitalization of Indonesia Syaria Stock Index market (ISSI) reached Rp3.464,2 trillion, or it was equal to $54,5 \%$ from the capitalization of Indonesia stock market which reached Rp6.352 trillion. The Analyst Capital life Syariah Fund Manager M. Al-Amin stated that the numbers of eminents in list of syaria stock were
335 stocks, it was around $60 \%$ towards the stock listed in Indonesia Stock Exchange. In 2016, the capitalization value of Indonesia Syaria Stock Index reached Rp3.175,05 trillion, this grew 22,15\% from the position of $\mathrm{Rp} 2.600,85$ trillion on the first period in a year before. In 2015, the market capitalization of ISSI has ever decreased until Rp346 trillion. (https://beimediahariini.wordpress.co m)

Based on the data of OJK, the amount of syariastok in 2016 reached 354 companies, or it increased 23 stocks from the position of 331 in 2015. However, if compared with the year 2013-2014, there was decrease of the amount of syaria stock. The number of syaria stock in 2013 and 2014 were 336 syaria stock and 334syaria stock.As on per 31 May 2017 there were 333 stocks. (https://beimediahariini.wordpress.co $\mathrm{m})$

OJK published the List of Syaria Stock (DES) in late May and November, which was effective on June $1^{\text {st }}$ and on December $1^{\text {st }} 2017$. OJK published 351 stocks in DES. From 351 emitent stocks and public company stocks, there were three emitent stocks and public company of syaria entity and 348 emitents which did not mention their activities based on syaria principle, but they were included to the criteria of syaria stock. From those 351, the biggest DES came from trade, service, and investment which were for about 90 stocks or around $25,64 \%$ out of the total of. Then, followed by property, real estate, building construction which were 59 stocks or $16,81 \%$, and basic industry and chemical industry 
for about 52 stocks or $14,81 \%$ out of the total of DES. (https://beimediahariini.wordpress.co m)

Based on the background of problems above, therefore, the formulation of the problem in this research is "Doleverage and profitability influence partially and simultaneously towardIslamic Social Reporting of company listed in Indosia Syaria Stock Index?'Based on formulation of the problem above, the aim of this research is tofind out the influence of leverage and profitability partially and simultaneously towards Islamic Social Reportingof company listed in IndosiaSyaria Stock Index.

\section{LITIRATURE RIVIEW}

In line with the increasing of the implementation of Corporate Social Reporting (CSR)in business, then the intention of creating social reporting also increased. There are so many opinions about the disclosure of socialreporting. SocialReportingis

the extension of the financial reporting system which refelects new estimation and was wider than the community in accordance with the roles of business community in economy. (Hannifa,2002).

Meanwhile, according to Gray et al.(1987) social reportingwas a process to communicate the environmental social effect due to the economic activity conducted by company to community. The rules of social reporting can be both accepted by some communities and refused by others. This was because the ethic code in socialreportingwas relative (Lewis and Unerman,1999).There was no way to decide the right ethic code. Besides, Grayetal.(1987)stated that identified responsibility of an organization is a problem because responsibility alsways changes all the times.

Siwarand Hossain (2009) stated that the basic foundations of Islam are aqidah (belief and faith), worship, and akhlaq (morality and ethics). Besides, the other principle for Muslim is tauhid (worshiping the only God Allah Subhanallahuwa Ta'ala)

One of the forms of accountability in the perspective of Islamic economic is the Social Reporting responsibility which was in line with the syaria principle. In conventional economic,this social reporting was known as the extension of financial reporting system which reflected the wider social expectation in relation with the role of community in economy or company activity.

Level ofleverageis about the ability of a company to finish its all responsibilities toother party. The company must explain to the investor, creditor and otherrelated party about their ability to pay loan and the impact of the loantowards the company activity. Company with high leveragelevel would have a push to give information and one of the information was a social information to the party outside. The disclosure would lessen the assymetric of information and uncertainty about the prospect of company in the future and this aimed at giving conviction to creditor that compay did not break covenants(agreement) (Ramadhani, 2016).

Company with high leverage had the responsibility to do wider 
disclosure than that of the company with lower leverage ratio. Kolsi (2012)in Rama and Meliawati (2014)argumented that company with haigher leverage ratio would be more careful than the company which depended much on capital loan.As a result, the company with high leverage ratio would disclose wider information. The research which was conducted by Pramudinata (2015) and Ramadhani (2016) proved that leverage influenced positively and it was significant to the disclosure of Islamic Social Reporting.

Disclosure of social responsibility reflected the company approach in doing dynamic and multidimensional adaptation with the environment. The relation between social responsibilities and company profitability which reflected that social reaction needed managerial style conducted by the management in order to make the company receive profit (Bowman and Haire,1976 in Sembiring,2003).

In Islam perspective, a company would disclose in a whole without seeing whether its company gave profit or not (Haniffa,2002).But Janggu(2004) argued that a company with higher profitability would disclose more information than that of with lower profitability.

According to Watts and Zimmerman (1986), a company with higher profitability would do a policy intervention. Therefore, this company would disclose detail information in its annual report to decrease its political cost and to show the financial performance to public. The reassarch conducted byOthman et al. (2009), Lestari (2013), andPratama, dkk (2018) mproved that profitability had both positive and significant impact to the level of disclosure in Islamic Social Reporting. Based on the formulation and theoretical approach which have been mentioned, therefore the hypothesis proposed in this research: $\mathrm{H} 1$ : Leverageinfluenced toward Islamic Social Reportingof the company listed as Indonesia Syaria Stock Index, H2: Profitability

influenced toward Islamic Social Reporting of the company listed as Indonesia Syaria Stock Index. H3: Leverage and profitability influenced simultaneously toward theIslamic Social Reportingof company listed as Indonesia Syaria Stock Index.

\section{METHOD}

This research was conducted in Indonesia stock Exchange through the legal site that was accessed online http://www.idx.co.id. The time dimension used was cross sectional time, which meant that this research was conducted in certain time. In this research, it was conducted in 2016. It was an explanation research with quantitative approach. The population of this research was all registered company as Indonesia Syaria Stock Index in 2016. Sampling technique used was nonprobability samplingwith purposive sampling. Dataused in this research was in the formof secondary data in 2016 annual report. That data was taken from the share market publication, especially one which was available in Indonesia Stock Exchange. The typesof data was a documenter data in the form of annual report in 2016 from the company registered in Indonesia Syaria Stock Index (ISSI). 
The Data analysis method used in this research was a multiple linear regression. This multiple linear regression study the form between two or more of independent variable (X) and dependent variable (Y). Meanwhile the dependent variable $(Y)$ in this research was in the form of response calculated based on the independent variables $(\mathrm{X})$.

To analyze Islamic Social Reportingas a dependent variable with some independent variables, it used multiple linear regressions. This reseach model was estimated by using OLS (Ordinary Least Square)method in each hypothesis. Normality test aimed at testing whether in the regression model, residual variable had normal distribution. Normality test used normal p-p plottest. The basic of the analysis was if the dots were spread surpressedly around diagonal line and in the same direction following its diagonal lines, it could be concluded that the data had a normal distribution (Ghozali, 2011).

Heterodexity testaimed to find out whether varianceof the residual data from one observation to other observation was different or stayed the same. The basic of analysis was if there was an organized pattern such as certain dots created patterns of ( wavy,widen, then narrow)then the Heteroscedasticity occurred. If there was no clear patternsspreadedover and under 0 on $\mathrm{Y}$ axis, there was no Heteroscedasticity (Ghozali, 2011).

Multicollinearity test was used totest whether in its reression model there was correlation among independent variables or not. Ingeneral, the value used to show the presence of multicollinearity with the value of Tolerance $\leq 0,10$ or equal to the value if $\mathrm{VIF} \geq 10$. A good regression model showed no problem of multicollinearity, (Ghozali, 2011).

Autocorrelation test was used to find out the existence of unusual assumption of classic autocorrelation which was correlation occurred between residual in one observation and other observation in the regression model.If the value of DW was between -2 and +2 or $2 \leq \mathrm{DW} \leq+2$ then, there was no autocorrellation(Ghozali, 2011).

Determinant Coefficient test was used to find out the value of contribution or the influence of independent variable quadrantingthe coefficient correlation. The value of determinancy coefficient was between zero and one. The small value of $R^{2}$ meant that the ability of independent variables to explain variation of dependent variables was really limited. The value which was closer to one meant that independent variable gave all information neede to produce dependent variables (Ghozali, 2011).

Method used to test hypothesis in this research was simultant significant test (F-test) and significant test of individual parameter ( $\mathrm{u} t$ test). $\mathrm{F}$ test showed if all independent variables inserted in the model had simultaneous influence to dependent variable. However, t-test showed how one individual variable could explain variation of dependent variables (Ghozali, 2011).

\section{RESULTS AND DISCUSSION}

Objects in this research were companies registered as Indonesia Syaria Stock Index(ISSI) in Indonesia Stock Exchange within period of observation in 2016. All the data used 
in this research received from the annual financial report published by Indonesia Stock Exchange.The choosing of sample used purposive sampling method in which the samples included in this research must fulfil certain criteria. After they were selected based on the criteria, then there would be final samples for about 179 companies.

Table2. Multi and Autocorrelation

\begin{tabular}{llll}
\hline Variable & Tolerance & VIF & $\begin{array}{l}\text { Durbin } \\
\text { Watson }\end{array}$ \\
\hline $\mathrm{X} 1$ & 0,999 & 1,001 & - \\
$\mathrm{X} 2$ & 0,999 & 1,001 & - \\
$\mathrm{X} 1, \mathrm{X} 2$ & - & - & 1,951 \\
\hline \multicolumn{3}{c}{ Based on table2above, it } \\
showed that the value of VIF
\end{tabular}

(Variance Inflation Factor) was 1,001which was less than 10 and the value of tolerancewas 0,999 which was over 0,1 in all variables used in this research. This condition showed that there was no perfect linear correlation among independent variables. Therefore, the regression model in this research could not find problem of multicollinearity and it has fulfilled the criteria of a good regression model. Besides, table 2 above showed that the value of DW (Durbin-Watson) resulted from the regression model was 1,928 . Because the value of DW was between -2and 2 or $-2 \leq 1,928 \leq 2$, thus, the model of regression in this research was free from autocorrelation problem

Table 3. Result of the Analysis of Multiple Linear Regression

\begin{tabular}{lllllll}
\hline Variable & B & t count & Sig. & R Square & F count & Sig. \\
\hline Constants & 0,313 & - & - & - & - & - \\
X1 & 0,012 & 1,455 & 0,148 & - & - & - \\
X2 & 0,089 & 15,240 & 0,000 & - & - & - \\
X1 and X2 & - & - & - & 0,573 & 117,966 & 0,000 \\
\hline
\end{tabular}

Based on table 3 above, the regression equation was as follow: $\mathrm{Y}=0,313+0,012 \mathrm{X}_{1}+0,089 \mathrm{X}_{2}$. That regression equation could be explained below: Constants of 0,313 ; it meant that if Leverage $\left(\mathrm{X}_{1}\right)$ and Profitability $\left(\mathrm{X}_{2}\right)$ was 0 , then the value disclosure of Islamic Social Reporting (Y) was $0,313 \%$. Regression coefficient of Leverage variable $\left(\mathrm{X}_{1}\right)$ was for about 0,012 ; it meant that other variable independent stayed the same and Leverage $\left(\mathrm{X}_{1}\right)$ experienced a raise for about $1 \%$, Thus, the value of Islamic Social Reportingdisclosure (Y) would raise for about $0,012 \%$. The coefficient was positive which meant that
Leverage $\left(\mathrm{X}_{1}\right)$ influenced positively toIslamic Social Reporting disclosure $(\mathrm{Y})$, the higher the Leverage $\left(\mathrm{X}_{1}\right)$ the higher disclosure of Islamic Social Reporting ( $\mathrm{Y}$ ) would beand vice versa. The lower theLeverage $\left(\mathrm{X}_{1}\right)$ the lower disclosure of Islamic Social Reporting (Y).

Coefficient of regression of Profitability variable $\left(\mathrm{X}_{2}\right)$ was 0,089 ; it meant that if the other independent variable stayed in the same value and Profitability $\left(\mathrm{X}_{2}\right)$ experienced an increase of $1 \%$, thus, the disclosure of Profitabilitay(Y) would increase $0,089 \%$. The coefficient was positive which meant that Profitability $\left(\mathrm{X}_{2}\right)$ influenced positively toward the 
disclosure of Islamic Social Reporting (Y), the higher the profitability $\left(\mathrm{X}_{2}\right)$ the higher the disclosure of Islamic Social Reporting (Y)and vice versa, The lower theLeverage $\left(\mathrm{X}_{1}\right)$ the lower disclosure of Islamic Social Reporting (Y).

Based on table 2 , the value resulted as the score of coefficient determinacy was (Adjusted $\mathrm{R}^{2}$ ) 0,573 or $57,3 \%$. This showed that disclosure of Islamic Social Reportingcould be explained by leverageand profitability,Meanwhile, the rest $42,7 \%$ was explained by other variables excluded in this research such as the size of board of directors, age of company, company size and etc.

Based on table2above, it was known that $F_{\text {count }}$ for about 117,966 in which $F_{\text {countwas }}$ bigger than $F_{\text {table }}$ (df1=2, df2=176, $\alpha=0,05)$ which was for about 3,047or 117,966>3,047. Besides, it was known the value ofsig was for about 0,00 in which sig value was smaller than 0,05 or $0,000<0,05$, thus Ho was rejected and $\mathrm{Ha}$ was accepted, it meant that leverageand profitabilitysimultaneously influence the disclosure of Islamic Social Reporting.

Then, it was known that the value of $t_{\text {countfor }}$ leveragevariable was $1,455 \mathrm{in}$ which the value of $\mathrm{t}_{\text {count }} \mathrm{Was}$ smaller than table $(d f=177, \alpha=0,05)$ which was for about 1,974 or 1,455 $<1,974$. Moreover, it was known that the value of sig.was 0,148 where the the value of sig.wasbiggerthan 0,05 or $0,148>0,05$ thus, Ho was accepted and Hawas rejected, it meant that leverageinfluenced insignificantly to the disclosure of Islamic Social Reporting.
Meanwhile, the value $t_{\text {countfor }}$ profitability variable for about 15,240 in which the value of $t_{\text {count }}$ was bigger than $t_{\text {table }}(\mathrm{df}=177, \alpha=0,05)$ which was 1,974 or $15,240>1,974$. Moreover, it was known the value of sig. was 0,000 in which sig. value was smaller than 0,05 or $0,000<0,05$ thus, Ho was rejected and Ha was accepted, it meant that profitability influenced significantly toward disclosure of Islamic Social Reporting.

The first hypothesis tested the impact of leveragetoward disclosure of Islamic Social Reporting. Theamount of the influence of leveragetoward disclosureofIslamic Social Reportingwas known from the value of Beta coefficientwhich was for about 0,012 , it showed that this was insignificant impact because the value of probability (sig) was 0,148 and it was bigger than 0,05. Because the value of probability (sig) leverageis bigger than 0,05 , therefore, leverageinfluenced positively and insignificantly toward the disclosure ofIslamic Social Reporting, thus the First Hypothesis (H1) was rejected. This result was supported by the rsearch conducted by Rama and Meliawati (2014) which found the same result.

Second hypothesis tested the influence of profitabilitytoward disclosure of Islamic Social Reporting. The value of influence of profitabilitytoward disclosure of Islamic Social Reporting. It was known from the value of Beta coefficient was 15,240 , showing that this was significant because the value of probability (sig) was $0,000<0,05$. Because the value of probability (sig) profitability smaller than 0,05 , meaning thatprofitability influenced 
positively and significantly to disclosure ofIslamic Social Reporting, therefore, the second Hyphothesis (H2) was Accepted.This result was supported by research conducted by Othman et al (2009),Lestari (2013), andPratama, dkk (2016) which found the same result.

The third hypothesis tested the impact of leverageand profitabilityaltogether toward the disclosure of Islamic Social Reporting. The amount of these leverageand profitability altogether towards the disclosure of Islamic Social Reportingwas known from the value of coefficient determinant which was for about 0,573 or $57,3 \%$. It showed a big significant impact because the value of probability (sig) was 0,000 and it is less than 0,05.

Because the simultaneous value of probability (sig) of leverageandprofitability towards the disclosure of Islamic Social Reportingwhich is less than 0,05 , it means leverageand profitabilitygave positive and significant impact towards Islamic Social Reporting,therefore, the third hypothesis(H3) was accepted.

\section{CONCLUSION}

Based on the result of the research, it can be concluded as follows: Leverage gave a positive impact and insignificant towards the disclosure ofIslamic Social Reportingin the company registered as Syaria Indonesia Stock Index (ISSI) in Indonesia Stock Exchange in 2016.

Profitability gave a positive and significant impact toward the disclosure ofI slamic Social
Reporting in the company registered as Syaria Indonesia Stock Index (ISSI) in Indonesia Stock Exchange in 2016

Leverage and profitability simultaneously positive and significant impact towards the disclosure of Islamic Social Reporting in the company registered as Syaria Indonesia Stock Index (ISSI) in Indonesia Stock Exchange in 2016

\section{REFERENCES}

Pramudinata, Andrian. 2015. Pengaruh Ukuran Perusahaan, Umur Perusahaan, Profitabilitas, dan Leverage Terhadap Pengungkapan Islamic Social Reporting pada Bank Umum Syariah di Indonesia. Skripsi Universitas Negeri Surakarta. Tidak dipublikasikan.

Gustani, 2015, Islamic Social Reporting (ISR) sebagai Model Pelaporan CSR. Institusi Bisnis Syariah, STIE SEBI.

Fitria, Soraya. \& Dwi Hartanti. 2010. Islam dan Tanggung Jawab Sosial: Studi Perbandingan Pengungkapan berdasarkan Global Reporting Iniviative Index dan Islamic Social Reporting Index. Simposium Nasional Akuntansi Ke-13, Purwokerto.

Haniffa, R. 2002. Social Reporting Disclosure: An Islamic Perspective. Indonesian Management \& Accounting Research. Vol. 1 (2): 128-146.

Haniffa, R. \& Hudaib M. (2007).

Exploring the ethical identity of Islamic banks via communication in annual reports. Journal of Business Ethics, 76(1), 97-116. 
Ghozali, Imam. 2011. Aplikasi Analisis Multivariate Dengan Program IBM SPSS 19. Semarang: Badan Penerbit Universitas Diponegoro.

Gray, R.H., Owen, D. and Maunders, K., 1987, Corporate Sosial Reporting: Accounting and Accountability, London : Prentice-Hall International.

Janggu, T., 2004, Corporate social disclosure of construction companies in Malaysia, Master Thesis, Universiti Teknologi MARA

Lestari, Puji. 2013. Determinants of Islamic Social Reporting In Syariah Banks: Case of Indonesia. International Journal of Business and Management Invention, 2(10), 28-34.

Lewis, Linda \& Jeffrey Unerman. 1999. Ethical Relativism: A Reason for Differences in Corporate Social Reporting. Critical Perspectives on Accounting. Vol. 10, p. 521547

Othman, R. et.al. 2009. Determinants of Islamic Social Reporting Among Top Shariah Approved Companies in Bursa Malaysia. Research Journal of International Studies. Vol. 12 (12): 4-20.

Othman, R., \& Thani, A.M. 2010. Islamic Social Reporting of Listed Companies in Malaysia. International Business \& Economics Research Journal, 12, 135144. and Reporting by Listed Companies in Zimbabwe. The International Journal of Accounting, 33, 605-631.
Putri, Tri Karina. 2014. Faktor-Faktor yang Mempengaruhi Islamic Social Reporting PerusahaanPerusahaan yang Terdaftar Pada Indeks Saham Syariah Indonesia (ISSI) Tahun 20112012. Skripsi Universitas Diponegoro. Tidak dipublikasikan

Sembiring, Edy Rismanda. 2003. "Karakter Perusahaan dan Pengungkapan Tanggung Jawab Sosial: Study Empiris Pada Perusahaan Yang Tercatat Di Bursa Efek Jakarta", SNA, 8, 2005, pp. 379-395.

Rama, Ali \& Meliawati. 2014. Analisis Determinan Pengungkapan Islamic Social Reporting: Studi Kasus Bank Umum Syariah Di Indonesia. EQUILIBRIUM: Jurnal Ekonomi Syariah, Vol.2, No.1, 2014.

Pratama, A. Nur Abdi, Syaiful Muchlis, \& Idra Wahyuni. $2018 . \quad$ Determinan Pengungkapan Islamic Social Reporting (Isr) Pada Perbankan Syariah Dengan Komisaris Independen Sebagai Variabel Moderating. ALMASHRAFIYAH: Jurnal Ekonomi, Keuangan dan Perbankan Syariah, Vol.1, No.2 April 2018.

Ramadhani, Febri. 2016. Pengaruh Ukuran Perusahaan, Profitabilitas, Leverage Dan Ukuran Dewan Pengawas Syariah Terhadap Pengungkapan Islamic Social Reporting (Studi Empiris Pada Bank Umum Syariah Di 
Indonesia Tahun 2010-2014). JOM Fekon, Vol.3, No.1, Februari 2016.

Siwar \& Hossain, 2009. An Analysis of Islamic CSR Concept and The Opinion of Malaysian Managers. Management of Environmental Quality : An International Journal Vol. 20 No. 3

Watts, Ross, Zimmerman, Jerold, L. 1986. "Positive Accounting
Theory," Prentice Hall, New Jersey. United States of America, 1986.

http://finansial.bisnis.com/read/2016 1002/9/588755/indekssaham-syariah-indonesiatumbuh-tertinggi-di-dunia diakses 20 juli 2017

https://beimediahariini.wordpress.co m/2017/07/21/kapitalisasipasar-syariah-menggemuk/ diakses 20 juli 2017 